Jacek Wojnicki

\title{
INSTYTUCJA RZĄDU REPUBLIKI CZARNOGÓRY W SYSTEMIE ORGANÓW WŁADZY
}

Rozwój instytucji rządu Czarnogóry związany jest z dwoma czynnikami: kształtowaniem się organizmu państwowego oraz rozwojem konstytucjonalizmu czarnogórskiego. Poniżej zostaną zaprezentowane węzłowe etapy formowania się władzy wykonawczej w państwie czarnogórskim oraz jugosłowiańskim (okres 1918-1992).

\section{Rys historyczny instytucji rządu i premiera}

Ziemie Czarnogóry dostały się do niewoli tureckiej w 1499 r. Kraina stanowiła domenę sułtana i zachowała pewną autonomię. Należy podkreślić, iż Czarnogórcy stanowili luźno związane ze sobą - często wrogie i zwalczające się - klany. Posiadali wspólnego księcia oraz rozlicznych przywódców - kniaziów, starostów i wojewodów zwoływanych na ogólny wiec - Skupsztinę. W ustroju Czarnogóry najsilniej zachowały się przeżytki patriarchalne. Ziemia stanowiła wspólną własność rodu i uprawiana była przez wszystkich jej członków. Islamizacja objęła jedynie część społeczeństwa, Cerkiew prawosławna zaś odgrywała ogromną rolę kulturalną, jednoczyła równocześnie wszystkie plemiona do walki z zaborcą ${ }^{1}$.

Za rządów Piotra I Njegoša (1781-1830) doszło do decydującej bitwy z osmańskim okupantem. W 1796r. pod wsią Kruše Czarnogórcy rozgromili doszczętnie albańską armię tureckiego dostojnika Mahmuda Paszy. Bitwa zadecydowała o uzyskaniu faktycznej niezależności przez Czarnogórę. W 1798 r. na dorocznym zgromadzeniu naczelników plemion w Cetinji uchwalono jednolity zbiór praw. W pierwszej

1 Zob. L. Podhorodecki, Jugosławia. Dzieje narodów, państw i rozpad federacji, Mada, Warszawa 2000, s. 67 i nast. 
połowie XIX wieku - w wyniku nieustannej walki z Turcją - Czarnogóra umacniała swoją niezależność. Wojny ze wspólnym wrogiem coraz bardziej zacieśniały jedność Czarnogórców z Serbami. Za rządów metropolity Piotra II (Petara), Petrovicia Njegoša (1830-1851), usunięto z kraju gubernatora weneckiego, ustanowiono 12-osobowy Senat złożony z przedstawicieli największych rodów. Nadano mu uprawnienia władzy zwierzchniej, choć faktycznie pełnił on funkcje doradcze. Piotr II ustanowił system sądownictwa i policję, wprowadził obowiązkowy podatek pieniężny. Po krwawych walkach w 1842 r. zawarł układ z Austrią, która uznała ostatecznie niepodległość Czarnogóry. W 1855 r. Skupsztina czarnogórska zatwierdziła Ogólny zbiór praw (Opšti zemaljski zakonik) określający zasady ustroju państwowego, kodeks praw cywilnych oraz przepisy podatku państwowego. Senat stał się równocześnie wyższą instancją sądową².

Panujący w Czarnogórze monarcha Mikołaj I (1860-1918) rządził w sposób samowładny, bez konieczności odwoływania się do opinii społecznej. W latach 1878-1903 w Serbii funkcjonowało ponad 20 rządów, podczas gdy w Czarnogórze u władzy pozostawał jeden - wojewody Božo Petrovicia. Powolny rozwój gospodarczy oraz silna władza jednostki wpływały spowalniająco na modernizacje państwa czarnogórskiego. Aż do 1909 r. Czarnogóra nie posiadała swojego pieniądza, a prawo zwyczajowe mieszało się z prawem pisanym ${ }^{3}$.

Po kongresie berlińskim (w 1878 r.), potwierdzającym niezależność Czarnogóry, przeprowadzono reformy administracyjne i kodyfikacje prawa. W 1879 r. zniesione zostały Senat oraz Skupsztina starszyzny plemiennej, natomiast w ich miejsce powołano nowy organ ustawodawczy - Radę Państwa liczącą 8 osób. Władza wykonawcza została skupiona w gabinecie ministrów, sądownictwo zaś podporządkowano Sądowi Najwyższemu4.

W grudniu 1905 r. - działając pod naciskiem społecznym - Mikołaj I oktrojował pierwszą konstytucję czarnogórską. Zgodnie z postanowieniami konstytucji do zadań księcia należało zatwierdzanie wszystkich ustaw, występowanie z inicjatywami legislacyjnymi, mianowanie ministrów oraz wydawanie dekretów. Członkowie parlamentu mieli być częściowo powoływani przez księcia, a częściowo wybierani w elekcji powszechnej. Zgromadzenie uzyskało uprawnienia inicjowania debat, opracowywania projektów ustaw oraz wnoszenia zmian do budżetu 5 .

2 Zob. W. Felczak, T. Wasilewski, Historia Jugosławii, Ossolineum, Wrocław 1985.

3 Zob. M. Tanty, Bałkany w XX wieku. Dzieje polityczne, Książka i Wiedza, Warszawa 2003, s. 38.

4 Zob. J. Skowronek, M. Tanty, T. Wasilewski, Słowianie południowi i zachodni. VI-XX wiek, Książka i Wiedza, Warszawa 2005, s. 430.

5 Zob. B. Jelavich, Historia Bałkanów. Wiek XX, Wyd. UJ, Kraków 2005, s. 49. 
Ukształtowanie się wspólnego państwa, zamieszkałego przez Słowian Południowych, nastąpiło w dwóch etapach. W listopadzie 1918 r. Wielkie Zgromadzenie Narodowe Czarnogóry (liczące 165 deputowanych) uchwaliło w Podgoricy detronizację króla Mikołaja I Petrovicia Njegoša oraz zjednoczenie Czarnogóry z Serbią pod wspólnym berłem dynastii Karadjordjeviciów ${ }^{6}$.

W grudniu 1918 r. powstało Królestwo Serbów, Chorwatów i Słoweńców (SHS) z królem Serbii jako monarchą nowego organizmu państwowego. Ustrój państwa określała ustawa zasadnicza uchwalona przez Zgromadzenie Ustawodawcze. Konstytucja widowdańska (od dnia św. Wita - 28 czerwca - Vidovdanski Ustav) z 1921 r. określała państwo jako monarchię dziedziczną ${ }^{7}$. Ustawa zasadnicza uznawała istnienie jednego narodu, który używał języka serbsko-chorwacko-słoweńskiego. Władzę ustawodawczą sprawował król wraz z jednoizbowym Zgromadzeniem Narodowym (Narodna Skupština). Kadencja parlamentu została określona na lat cztery. Monarcha miał również sprawować władzę wykonawczą za pośrednictwem ministrów - odpowiedzialnych przed monarchą oraz parlamentem. Monarcha reprezentował państwo w stosunkach z zagranicą, wypowiadał wojnę, stanowił o pokoju, mianował i odwoływał premiera. Wprowadzał stan wyjątkowy, jednocześnie był najwyższym dowódcą armii. Zgodnie z konstytucją król miał więcej praw od parlamentu.

Sytuacja w państwie daleka była od ustabilizowania. Politycy chorwaccy oraz słoweńscy zarzucali królowi prowadzenie polityki wielkoserbskiej. Warto zaznaczyć, iż Czarnogóra nie została wydzielona jako odrębna kraina geograficzna i historyczna. Serbowie traktowali ją generalnie jako część swoich ziem. W styczniu 1929 r. król Aleksander dokonał zamachu stanu oraz wprowadził dyktaturę. Król wydał jednocześnie dekret o władzy państwowej i królewskiej, na mocy którego przejmował pełnię władzy ustawodawczej i wykonawczej, znosząc konstytucję. Skupsztina została rozwiązana, wydano zakaz istnienia partii narodowych. Powołano do życia jedną organizację polityczną - Jugosłowiańską Partię Narodową. Dokonano centralizacji władzy, przejawem tej tendencji była zmiana nazwy państwa na Królestwo Jugosławii (Kraljevina Jugoslavija) ${ }^{9}$.

Nowa ustawa zasadnicza została ogłoszona we wrześniu 1931 roku $^{10}$. Król Aleksander ustanowił monarchię konstytucyjną. Władzę królewską ograniczał jedynie

6 Zob. W. Szulc, Przemiany gospodarcze i społeczne w Jugosławii w okresie międzywojennym (1918-1941), Wyd. Nauk. UAM, Poznań 1980, s. 25.

7 Zob. Konstytucja Królestwa Serbów, Chorwatów i Słoweńców (ogłoszona 28 czerwca 1921 r.), w: Nowe konstytucje, red. J. Makowski, Nakł. Księgarni F. Hoesicka, Warszawa 1925.

8 Zob. E. Mizerski, Jugosłowiański system przedstawicielski 1918-1990, Wyd. Adam Marszałek, Toruń 1999, s. 29 i nast.

9 Zob. W. Walkiewicz, Jugosławia - byt wspólny i rozpad, Trio, Warszawa 2000, s. 75 i nast.

${ }_{10}$ Zob. Ustav Kraljevine Jugoslavije, „Službene Novine” 1931, broj 900. 
dwuizbowy parlament - Skupsztina oraz Senat. Posłowie do Skupsztiny oraz połowa składu Senatu byli wybierani w wyborach powszechnych, pozostałych senatorów mianował natomiast generalnie monarcha. Król był pierwszym reprezentantem narodu oraz zwierzchnikiem władz: ustawodawczej, wykonawczej oraz sądowniczej. Monarcha wydawał ustawy, posiadał prawo weta. Król podejmował decyzje w sprawie ustaw, na temat których powstały rozbieżności między obu izbami parlamentu. Król posiadał również prawo rozwiązania obu izb parlamentu przed upływem kadencji. Ministrowie byli odpowiedzialni przed monarchą ${ }^{11}$.

Po 1945 r. władzę w Jugosławii przejęła partia komunistyczna (z marszałkiem Josipem Brozem Tito na czele) ${ }^{12}$. Komuniści zdobyli popularność jako siła oporu wobec hitlerowskiego i włoskiego najeźdźcy. Marszałek Tito już w 1943 r. zadeklarował wolę budowy federacji z sześcioma pełnoprawnymi republikami (Deklaracja Antyfaszystowskiej Rady Wyzwolenia Narodowego Jugosławii AVNOJ z 29 listopada 1943 r. ogłoszona w Jajce). Czarnogóra została oficjalnie wydzielona jako jedna $\mathrm{z}$ republik związkowych.

W styczniu 1946 r. Skupsztina przyjęła nową ustawę zasadniczą - wzorowaną na Konstytucji ZSRR z 1936 roku $^{13}$. Parlament (Skupsztina Ludowa) składał się z dwóch izb - Rady Związkowej oraz Rady Narodowości. Ograniczenie kompetencji parlamentu de facto wynikało z przekazania większości kompetencji decyzyjnych do instancji partyjnych (Biura Politycznego KPJ, następnie Prezydium ZKJ), a także wyeliminowania ugrupowań opozycyjnych z ław poselskich.

Pewne zmiany w funkcjonowaniu Skupsztiny nastąpiły po 1950 r. (czyli po zerwaniu bliskich relacji z ZSRR oraz wprowadzeniu tzw. samorządowego systemu władzy $)^{14}$. Skupsztina stała się organem samorządu społeczno-politycznego, szczegółowe funkcje parlamentu były określane na mocy kolejnych ustaw zasadniczych $\left(1953^{15}\right.$, $1963^{16}$ oraz $1974^{17}$ ). Zmianie ulegała także budowa parlamentu (od pięcioizbowej - konstytucja z 1963 r., do dwuizbowej - konstytucja z 1974r.). Na mocy ostat-

11 Zob. W. Szulc, op.cit., s. 35.

${ }^{12}$ Zob. M. Tanty, Bałkany..., op.cit., s. 278 i nast.

13 Zob. Konstytucja Federacyjnej Ludowej Republiki Jugosławii z 31 stycznia 1946 r., w: Nowe konstytucje państw europejskich, red. L. Gelberg, Polski Instytut Spraw Międzynarodowych, Warszawa 1949.

14 Zob. B. Ryś, Jugosłowiański system samorządowy, Instytut Krajów Socjalistycznych PAN, Warszawa 1986.

15 Zob. Ustawa Konstytucyjna o podstawach ustroju społecznego i politycznego Federacyjnej Ludowej Republiki Jugosławii z 13 stycznia 1953 r., w: Konstytucja Federacyjnej Ludowej Republiki Jugosławii, Warszawa 1957.

16 Zob. Konstytucja Socjalistycznej Federacyjnej Republiki Jugosławii z 7 kwietnia 1963 r., Sekretariat Związkowej Rady Wykonawczej, Belgrad 1964.

17 Zob. Konstytucja Socjalistycznej Federacyjnej Republiki Jugosławii, wstęp: J. Ciemniewski, Ossolineum, Wrocław-Warszawa-Kraków-Gdańsk 1975. 
niej, „titowskiej” konstytucji (1974) ${ }^{18}$, Skupsztina Związkowa składała się z: Rady Związkowej (220 mandatów) i Rady Republik oraz Okręgów Autonomicznych (88 mandatów).

Zgodnie z konstytucją z 1974 r. do kompetencji parlamentu związkowego (Skupsztiny SFRJ) ${ }^{19}$ należały: decyzje o zmianie konstytucji SFRJ, rozpatrywanie i ustalanie podstaw polityki wewnętrznej i zagranicznej, ustawodawstwo związkowe oraz uchwalanie innych przepisów i aktów ogólnych, w tym społecznego planu państwa związkowego, decydowanie o wojnie i pokoju, ratyfikowanie umów międzynarodowych, ustalanie polityki wykonywania ustawodawstwa związkowego oraz innych przepisów i aktów ogólnych, wybieranie i odwoływanie organów związkowych (Związkowa Rada Wykonawcza, Sąd Konstytucyjny Jugosławii, Sąd Najwyższy Jugosławii, Narodowy Sąd Gospodarczy) wraz ze sprawowaniem nad ich działalnością kontroli politycznej i nadzoru społecznego oraz wykonywanie innych zadań konstytucyjnie określonych.

Związkowa Rada Wykonawcza (rząd federacji - Savezno Izvršno Vijeće) była organem Skupsztiny SFRJ, któremu powierzono funkcje polityczno-wykonawcze w ramach praw i obowiązków federacji. Relacje najwyższych organów władzy państwowej federacji charakteryzowały się nadrzędnością Skupsztiny, co podkreślały normy konstytucji w przedmiocie wyboru i odwoływania SIV oraz kontroli jej działalności, jak również odpowiedzialności przez Skupsztiną. Prezydent SFRJ posiadał prawo wskazywania jednego z członków ze Skupsztiny jako kandydata na przewodniczącego SIV.

Wyboru przewodniczącego SIV oraz jej członków dokonywały obie izby parlamentu związkowego. Mandat delegata do Skupsztiny wybranego do Związkowej Rady Wykonawczej ulegał wygaśnięciu. SIV była organem wykonawczym Skupsztiny SFRJ. Równocześnie w miejsce jednej sfery działania, określanej jako działalność wykonawcza i zarządzająca, wprowadzone zostały dwie różne funkcje realizowane pod stałym zwierzchnictwem naczelnego organu przedstawicielskiego ${ }^{20}$. Funkcję polityczną - wykonawczą realizowała SIV, natomiast administracyjną (bezpośredniego zarządzania) - sekretarze i podsekretarze usytuowani poza SIV.

18 Zob. E. Zieliński, Skupsztyna SFRJ, PWN, Warszawa 1978

19 Por. J. Ciemniewski, Ustawa w jugosłowiańskim systemie konstytucyjnym, Zakład Narodowy im. Ossolińskich, Wrocław 1977, s. 78 i nast.; B. Zawadzka, Model przedstawicielstwa socjalistycznego, Zakład Narodowy im. Ossolińskich, Wrocław 1980, s. 325 i nast.

20 Zob. R. Chruściak, Zagadnienie pozycji ustrojowej rządu w ZSRR i w innych państwach Europy Wschodniej, w: „Studia konstytucyjne”, red. Z. Jarosz, Centralny Ośrodek Metodyczny Studiów Nauk Politycznych, Warszawa 1990, s. 208 i nast. 
Konstytucja Republiki Czarnogóry z 1992 roku $^{21}$ stanowiła wyraz zachodzących przemian ustrojowych w ramach republik jugosłowiańskich. Rząd Republiki Czarnogóry sprawował władzę wykonawczą, wydawał rozporządzenia, zarządzenia i inne decyzje w celu wykonywania delegacji zawartych w konstytucji oraz wydanych na podstawie ustaw. W skład rządu wchodzili: premier, wicepremierzy oraz ministrowie. Członek rządu będący deputowanym do Skupsztiny nie musiał zrzekać się mandatu deputowanego. Rząd ponosił odpowiedzialność przed parlamentem $^{22}$. Istotną datą w najnowszej historii Czarnogóry jest 21 maja 2006 r. - odbyło się wówczas referendum ogólnonarodowe, w którym opowiedziano się (stosunkiem głosów 55:45) za zerwaniem unii państwowej z Serbią. Dnia 3 czerwca 2006 roku Skupsztina proklamowała Deklarację Niepodległości.

\section{Konstytucyjne podstawy funkcjonowania rządu i premiera}

Najważniejszym aktem prawnym regulującym ustrój polityczny Republiki Czarnogóry jest Konstytucja Republiki Czarnogóry z 22 października 2007 roku ${ }^{23}$. Ustrojodawca definiuje Czarnogórę jako niezawisłe i suwerenne państwo o republikańskim modelu rządów. Czarnogóra jest określana jako państwo obywatelskie, demokratyczne, zorientowane ekologicznie, socjalne, oparte na rządach prawa (art. 1 konstytucji). Najwyższym suwerenem są obywatele posiadający czarnogórskie obywatelstwo. Obywatele sprawują władzę państwową w sposób bezpośredni lub za pośrednictwem swoich swobodnie wybranych przedstawicieli (art. 2 konstytucji). Władza państwowa oparta jest na monteskiuszowskiej zasadzie trójpodziału władzy. Ustrojodawca definiuje Skupsztinę jako piastuna władzy ustawodawczej, Rząd - jako władzę wykonawczą, a niezależne sądy - jako władzę wykonawczą. Konstytucja precyzuje, iż władza jest ograniczona postanowieniami ustawy zasadniczej oraz innych ustaw. Relacje pomiędzy władzami państwowymi opierają się na dwóch zasadach: równowagi i wzajemnej kontroli. Charakterystyczne jest, iż prezydent Republiki nie jest zaliczany do egzekutywy, a definiowany konstytucyjnie jako najwyższy reprezentant państwa (art. 11 konstytucji).

${ }^{21}$ Zob. Ustav Republike Crne Gore, „Službeni list RCG” 1992, broj 48.

22 Zob. J. Wojnicki, System konstytucyjny Serbii i Czarnogóry, Wyd. Sejmowe, Warszawa 2005, s. 51 i nast.

${ }^{23}$ Zob. Ustav Republike Crne Gore, „Službeni list RCG” 25 oktobar 2007, broj 1. 


\section{Skład i powoływanie oraz zasady działania rządu}

Ustrojodawca określa skład rządu Republiki Czarnogóry i wymienia w tym kontekście: premiera, jednego lub więcej wicepremierów oraz ministrów ${ }^{24}$. Charakterystyczna jest konstytucjonalizacja urzędu wicepremiera, raczej niespotykana w europejskich konstytucjach.

Powołanie nowego rządu jest procedurą złożoną i podzieloną pomiędzy uprawnienia prezydenta Republiki oraz Zgromadzenia. Pierwszy krok należy do głowy państwa - prezydent posiada konstytucyjny obowiązek przedstawienia Skupsztinie w ciągu 30 dni od dnia ukonstytuowania się parlamentu mandatariusza (którego należy traktować jako kandydata na premiera ${ }^{25}$. Mandatariusz jest zobowiązany do przedstawienia Zgromadzeniu oświadczenia o programie i składzie rządu. Konstytucja określa wyraźny termin na czynności związane z formowaniem nowego rządu oraz sankcję za ich niedotrzymanie. Skupsztina ulega bowiem rozwiązaniu w przypadku, gdy nie wybierze rządu w ciągu 90 dni od zgłoszenia przez prezydenta pierwszego mandatariusza (art. 92 konstytucji) ${ }^{26}$. Parlament decyduje o zaakceptowaniu programu i składu nowego rządu w jednym glosowaniu (art. 103 konstytucji). Konstytucja przyznaje Skupsztinie uprawnienie do wyboru oraz odwołania premiera oraz pozostałych członków rządu (art. 82 konstytucji). Ustrojodawca stanowi, iż do przegłosowania wspomnianych decyzji wymagana jest większość ustawowej liczby deputowanych - 41 z ogólnej liczby 81 (art. 91 konstytucji).

Ustrojodawca precyzuje tzw. zasadę imcompabilitas (czyli zasadę niepołączalności urzędów publicznych). Premier oraz członkowie rządu nie mogą sprawować mandatu deputowanego, pełnić innej publicznej funkcji, ani w sposób zawodowy zajmować się inną działalnością (art. 104 konstytucji).

Warto zwrócić uwagę, iż ustrojodawca precyzuje okoliczności wygaśnięcia mandatu rządu Republiki. Pierwsza przesłanka ma miejsce w sytuacji zakończenia kadencji Zgromadzenia. Druga okoliczność jest związana z udzieleniem wotum zaufania lub nieotrzymaniem wotum nieufności. Natomiast trzecia przesłanka ma miejsce w sytuacji nieprzedłożenia i nieuchwalenia budżetu państwa do 31 marca roku budżetowego. Konstytucja jednocześnie stanowi, iż rząd w stanie dymisji pełni

${ }^{24}$ Obecny rząd Milo Djukanovicia składa się z premiera, trzech wicepremierów oraz 18 ministrów (dane na dzień 10.11.2010).

${ }^{25}$ W dotychczasowej praktyce konstytucyjnej Republiki Czarnogóry po 1990 r. misję utworzenia rządu sześciokrotnie otrzymał Milo Djukanović (1991, 1993, 1997, 2003, 2008, 2009), a jeden raz jego bliski współpracownik Željko Šturanović (2006).

26 Okoliczność taka miała miejsce w dniu 19 lipca 2002 roku, gdy nie powiodła się trzecia misja utworzenia rządu przez Filipa Vujanovicia. 
swoje obowiązki do momentu powołania nowego rządu. Uprawnienia wspomnianego rządu są pomniejszone o prawo występowania $\mathrm{z}$ wnioskiem o rozwiązanie Skupsztiny (art. 110 konstytucji).

\section{Zadania i uprawnienia rządu i premiera}

Kompetencje rządu Republiki Czarnogóry określa w sposób enumeratywny art. 100 ustawy zasadniczej. Do zadań rządu należy prowadzenie polityki wewnętrznej oraz zagranicznej państwa. Rząd wykonuje ustawy i inne akty prawne, a także jest zobowiązany do wydawania rozporządzeń wykonawczych $\mathrm{w}$ celu realizacji ustaw. W zakresie polityki zagranicznej do uprawnień rządu należy podpisywanie umów i porozumień międzynarodowych. Rząd podejmuje także decyzje o uznaniu przez Republikę Czarnogóry innych państw oraz o nawiązaniu z nimi stosunków dyplomatycznych i konsularnych. Do uprawnień rządu należy także wskazywanie ambasadorów i szefów innych misji dyplomatycznych będących przedstawicielami Republiki. Na wniosek rządu w tej sprawie nominacje nadaje prezydent Republiki.

W relacjach rządu z parlamentem należy wymienić obowiązek rządu opracowania i przestawiania Zgromadzeniu projektu budżetu, sprawozdania z jego wykonania oraz przedkładania programu rozwoju społeczno-gospodarczego państwa. Rząd dysponuje także prawem do inicjatywy ustawodawczej oraz do wnioskowania o przeprowadzenie ogólnonarodowego referendum (art. 92 oraz 93 konstytucji) ${ }^{27}$. Należy również wspomnieć o kompetencji rządu odnośnie rozwiązania Skupsztiny. W przypadku, gdy parlament przez dłuższy czas nie wykonuje swoich obowiązków, rząd może rozwiązać Skupsztinę. Przed podjęciem stosownej decyzji wymagane jest przeprowadzenie konsultacji z przewodniczącym Zgromadzenia oraz szefami klubów parlamentarnych. Rozwiązanie Zgromadzenia następuje na mocy dekretu prezydenta Republiki ${ }^{28}$ (art. 92 konstytucji). Godzi się nadmienić, iż rząd Republiki nie może skorzystać ze swoich uprawnień w przedmiotowej sprawie w czasie obowiązywania stanów nadzwyczajnych, w trakcie rozpatrywania wniosku o udzielenie wotum nieufności w stosunku do rządu, a także w pierwszych i ostatnich trzech miesiącach funkcjonowania Zgromadzenia (art. 92 konstytucji). Rząd posiada także

\footnotetext{
${ }^{27}$ Należy wspomnieć, iż prawem inicjatywy ustawodawczej dysponują w Republice Czarnogóry także deputowani oraz grupa co najmniej 6 tysięcy wyborców. Z kolei prawo zgłoszenia wniosku o zarządzenie ogólnonarodowego referendum przysługuje również prezydentowi, grupie co najmniej 25 deputowanych oraz grupie co najmniej $10 \%$ wyborców.

${ }^{28}$ W dotychczasowej praktyce konstytucyjnej Republiki Czarnogóry trzykrotnie głowa państwa dokonywała rozwiązania Zgromadzenia Republiki na wniosek rządu (w 1998, 2001 oraz 2009).
} 
prawo do wniesienia pod obrady parlamentu wniosku o samorozwiązanie Zgromadzenia $^{29}$ (art. 84 konstytucji).

Uprawnienia rządu Republiki ulegają rozszerzeniu w sytuacji wprowadzenia stanów nadzwyczajnych (stanu wojennego oraz stanu wyjątkowego). Rząd jest upoważniony do wydawania dekretów z mocą ustawy w sytuacji, gdy Zgromadzenie nie może się zebrać na posiedzenie. Ustrojodawca precyzuje jednakże, iż dekrety powyższe wymagają przedłożenia parlamentowi na najbliższej możliwej sesji (art. 101 konstytucji).

\section{Odpowiedzialność rządu i premiera}

Zgodnie z regułami obowiązującymi w systemie parlamentarno-gabinetowym rząd ponosi wyłączną odpowiedzialność przez organem przedstawicielskim, jakim jest parlament.

Konstytucja stanowi, iż zarówno rząd, jak i ministrowie mogą zostać zdymisjonowani. Jednocześnie należy zwrócić uwagę, iż dymisja premiera oznacza automatycznie dymisję rządu ${ }^{30}$. Premier może zgłosić do parlamentu wniosek o zwolnienie ministra z urzędu (art. 105 konstytucji).

Parlament posiada prawo do zgłoszenia i uchwalenia wotum nieufności w stosunku do rządu ${ }^{31}$. Wniosek w przedmiotowej sprawie może wnieść grupa licząca co najmniej 27 deputowanych. Po odrzuceniu wspomnianego wniosku, następny - odnoszący się do tego samego rządu - może być wniesiony po upływie 90 dni (art. 107 konstytucji). Do przegłosowania wniosku wymagana jest większość ustawowej liczby deputowanych - 41 z ogólnej liczby 81 (art. 91 konstytucji). Procedurę rozpatrywania wniosku szczegółowo omawia Regulamin Organizacyjny Zgromadzenia $^{32}$. Wspomniany wniosek jest składany na ręce przewodniczącego parlamentu. Do jego obowiązków należy skierowanie wniosku do deputowanych oraz zawiadomienie rządu Republiki (art. 194 regulaminu). Nad złożonym wnioskiem Zgromadzenie przeprowadza debatę. Na początku debaty głos zabierają: przedstawiciel wnioskodawców, uzasadniając wniosek, oraz premier, który odnosi się do zgłoszonych

${ }^{29}$ Należy dodać, iż wniosek w sprawie samorozwiązania Zgromadzenia mogą także złożyć prezydent Republiki oraz grupa co najmniej 25 deputowanych.

${ }^{30} \mathrm{~W}$ dotychczasowej praktyce konstytucyjnej Republiki Czarnogóry premier dwukrotnie podawał się do dymisji: 19 kwietnia 2002 r. Filip Vujanović oraz 28 lutego 2009 r. Željko Šturanović.

${ }^{31} \mathrm{~W}$ dotychczasowej praktyce konstytucyjnej Republiki Czarnogóry Zgromadzenie jeden raz uchwaliło wotum nieufności w stosunku do rządu - dotyczyło to rządu Filipa Vujanovicia (22 maja 2002 r.).

32 Zob. Poslovnik Skupštine Crne Gore (prečišćeni tekst), „Službeni List Crne Gore” 2010, broj 7. 
zarzutów. Po debacie Zgromadzenie przeprowadza głosowanie nad przyjęciem bądź odrzuceniem wspomnianego wniosku (art. 195 regulaminu). Podobna procedura ma zastosowanie w przypadku składania przez rząd wniosku o wotum zaufania. Omawiany wniosek $\mathrm{w}$ formie pisemnej składany jest na ręce przewodniczącego parlamentu. Nad wnioskiem Zgromadzenie przeprowadza debatę. Jako pierwszy zabiera w niej głos premier, uzasadniając prośbę o udzielenie zaufania przez Skupsztinę w stosunku do rządu (art. 196 regulaminu). Decyzja o udzieleniu wotum zaufania bądź wotum nieufności w stosunku do rządu jest podejmowana przez Zgromadzenie w głosowaniu jawnym. Deputowani wypowiadają się za wnioskiem lub przeciw niemu. W przypadku nieuzyskania zaufania przez rząd premier powiadamia o tym fakcie prezydenta Republiki (art. 197 regulaminu).

Kolejną formą kontroli działalności rządu przez parlament jest prawo deputowanych do zgłoszenia interpelacji. Interpelacja jest zgłaszana $\mathrm{w}$ formie pisemnej i dotyczy działalności władzy wykonawczej. Uprawnienie do zgłoszenia interpelacji przysługuje grupie co najmniej 27 deputowanych. Odpowiedź na zgłoszoną interpelację winna być udzielona przez rząd w ciągu 30 dni (art. 108 konstytucji). Regulamin Organizacyjny Zgromadzenia wymienia dodatkowo możliwość zadawania pytań przez deputowanych członkom rządu Republiki. Dodatkową formą kontroli jest możliwość zadania pytania szefowi rządu (tzw. godzina premiera). Co najmniej raz na dwa miesiące na sesji plenarnej Skupsztiny premier przez godzinę odpowiada na tzw. pytania bieżące - dotyczące aktualnej działalności rządu. Zapytanie nie może trwać dłużej niż 5 minut, a odpowiedź premiera także nie powinna przekroczyć 5 minut (art. 187 regulaminu). Deputowany w czasie jednego posiedzenia może zadać co najwyżej dwa pytania. Czas na postawienie jednego pytania przez deputowanego wynosi trzy minuty. Na zapytanie pisemne, skierowane do przewodniczącego parlamentu, odpowiedzi udziela premier lub inny członek rządu także w formie pisemnej. Odpowiedź winna zostać udzielona w ciągu 20 dni od daty złożenia zapytania (art. 190-191 regulaminu). Deputowanemu służy prawo do skomentowania otrzymanej odpowiedzi w wypowiedzi trwającej maksymalnie do trzech minut. Ma także prawo do zadania zapytania precyzującego w ciągu kolejnej minuty swojej wypowiedzi. Odpowiedź ze strony przedstawiciela rządu na zapytanie precyzujące kończy debatę w przedmiotowej kwestii (art. 192-193 regulaminu).

Inną formą funkcji kontrolnej sprawowanej przez Zgromadzenie jest możliwość powołania komisji śledczej odnoszącej się do nieprawidłowości w pracach rządu. Wniosek o powołanie komisji śledczej musi złożyć grupa co najmniej 27 deputowanych (art. 109 konstytucji).

Rząd może zgłosić wniosek o wotum zaufania w Zgromadzeniu (art. 106 konstytucji). Nieprzychylenie się przez parlament do przedłożonego wniosku 
skutkuje dymisją rządu (art. 105 konstytucji). Do przegłosowania wniosku o udzielenie rządowi zaufania wymagana jest większość ustawowej liczby deputowanych - 41 z ogólnej liczby 81 (art. 91 konstytucji).

\section{Rząd a partie polityczne}

Sytuacja społeczno-polityczna w Czarnogórze pod koniec lat 80. XX wieku rozwijała się pod przemożnym wpływem wydarzeń w sąsiedniej republice - Serbii. Wiele przesłanek (zarówno historycznych, gospodarczych, jak i kulturowych) spowodowało, iż Czarnogóra stanowiła przykład najwierniejszej republiki względem Serbii. W styczniu 1989 r. serbski przywódca, Slobodan Milošević, doprowadził do zmiany kierownictwa republikańskiej partii komunistycznej. Nowym przewodniczącym Związku Komunistów Czarnogóry został Momir Bulatović, który należał do zwolenników utrzymania federacji jugosłowiańskiej w postaci scentralizowanej, nawet przy użyciu argumentów militarnych ${ }^{33}$.

Pierwsze rywalizacyjne wybory w Czarnogórze miały miejsce 9 grudnia $1990 \mathrm{r}$. Zakończyły się one znacznym triumfem rządzącego ugrupowania postkomunistycznego - Związku Komunistów Czarnogóry, przekształconego w lipcu 1990 r. w Demokratyczną Partię Socjalistów Czarnogóry (DPS). Na listy tej partii padło ponad 58,3\% głosów. Na drugim miejscu, z zaledwie 14,1\% głosów, uplasowała się koalicyjna lista Związku Sił Reformatorskich (SRS) ówczesnego premiera jugosłowiańskiego, Ante Markovicia, oraz Związku Liberalnego (LSCG). Trzecie miejsce zajęła Partia Narodowa (NS), uzyskując 13,3\% głosów, natomiast jako ostatnia wprowadziła swoich kandydatów do parlamentu Koalicja Demokratyczna (10,5\%). Podział mandatów ukształtował się w sposób następujący: DPS - 83 mandaty, SRS razem z LSCG - 17, NS - 13 oraz Koalicja Demokratyczna - 12. W lutym 1991 r. na czele rządu zdominowanego przez DPS stanął Milo Djukanović3 ${ }^{34}$.

Kolejna elekcja do Zgromadzenia Republiki Czarnogóry odbyła się w grudniu 1992 r. Potwierdziła ona dominującą pozycję Demokratycznej Partii Socjalistów. Jej kandydatów poparło ponad 43\% głosujących. Drugie miejsce zajęła Partia Narodowa, uzyskując ponad 13\% głosów. Na trzecim miejscu znalazł się Liberalny Związek Czarnogóry z poparciem sięgającym 12,4\% głosów. Czwarte miejsce zajęła Serbska Partia

${ }^{33}$ Stownik Biograficzny Europy Środkowo-Wschodniej XX wieku., red. W. Roszkowski, J. Kofman, Rytm, Warszawa 2005, s. 158; A. LeBor, Milosevic: A Biography, Bloomsbury, London 2002, s. 104 i nast.

${ }_{34}$ Zob. K. Krysieniel, J. Wojnicki, Partie i systemy partyjne państw byłej Jugosławii, Akademia Humanistyczna im. A. Gieysztora, Pułtusk-Warszawa 2009, s. 115 i nast. 
Radykalna (SRS) zyskująca poparcie wśród ludności serbskiej - 7,7\% głosów. Jako ostatnie ugrupowanie swoich deputowanych zdołała wprowadzić Partia Socjaldemokratyczna - SDP (ok. 4,5\% głosów). Podział mandatów w Skupsztinie przestawiał się następująco: DPS - 46, NS - 14, LSCG - 13, SRS - 8 oraz SDP - 4 mandaty ${ }^{35}$. Misję utworzenia nowego rządu ponownie otrzymał Milo Djukanović.

Kolejna elekcja parlamentarna miała miejsce w listopadzie 1996 r. Najwięcej głosów uzyskała rządząca Demokratyczna Partia Socjalistów (ponad 51\%). Na główne ugrupowanie opozycyjne wyrosła Partia Narodowa, która postanowiła utworzyć koalicję z LSCG. Uczestniczyła ona w wyborach pod nazwą Narodna Unia, a jej kandydatów poparło 25,6\% glosujących. Frekwencja w wyborach wyniosła $66,9 \%$ uprawnionych do głosowania. Podział mandatów w Zgromadzeniu Republiki przedstawiał się w sposób następujący: DPS - 45, NS - 19 oraz 7 mandatów dla mniejszych ugrupowań ${ }^{36}$. Misję utworzenia rządu po raz trzeci otrzymał Milo Djukanović.

Kluczowym momentem w kształtowaniu czarnogórskiej sceny politycznej był rozłam w rządzącym ugrupowaniu postkomunistycznym. W 1997 r. zwycięstwo $\mathrm{w}$ walkach wewnątrzpartyjnych odniosło skrzydło utożsamione $\mathrm{z}$ szefem rządu, Milo Djukanoviciem. W wyniku wspomnianego sporu wewnętrznego powstały dwa konkurencyjne ugrupowania - zwolennicy Milo Djukanovicia pozostali w szeregach DPS, natomiast zwolennicy bliższych związków z Serbią utworzyli w lutym 1998 r. Socjalistyczną Partię Ludową (SNP) ${ }^{37}$.

Testem popularności dla nowo ukształtowanej sceny politycznej stały się wybory w maju 1998 r. (przedterminowe). Główna rywalizacja toczyła się pomiędzy Demokratyczną Partią Socjalistów a Sojuszem Ludzi Pracy utworzonym wokół Socjalistycznej Partii Ludowej. Ostatecznie DPS uzyskała 49,5\% głosów, a SNP - ponad 36\%. Podział mandatów kształtował się następująco: DPS - 43 mandaty, natomiast SNP $-29^{38}$. Swoich deputowanych wprowadził także Liberalny Związek Czarnogóry (5 mandatów oraz 6,3\% głosów) ${ }^{39}$. Szefem nowego rządu, zdominowanego przez polityków DPS, został Filip Vujanović.

Kolejne wybory do Skupsztiny zostały przeprowadzone w kwietniu 2001 r. Ugrupowanie prezydenta Milo Djukanovicia, skupione w koalicji „Zwycięstwo Czarnogóry”, uzyskało ponad $42 \%$ głosów. Na drugim miejscu ulokował się opozycyjny blok „Razem dla Jugosławii”, na którego kandydatów oddano 40,6\% głosów. Liberalny

${ }^{35}$ Zob. www.parties-and-elections.de/montenegro.html, 15.04.2011.

36 Ibidem.

37 Zob. R. Thomas, The Politics of Serbia in the 1990, Columbia University Press, New York 1999, s. 379 i nast.

${ }^{8}$ Zob. J. Stańczyk, Jugosławia (Serbia i Czarnogóra), w: „Europa Środkowo-Wschodnia” 7-8 (1997-1998), Instytut Studiów Politycznych PAN, Warszawa 2000, s. 100 i nast.

${ }^{39}$ Zob. www.parties-and-elections.de/montenegro.html, 15.04.2011. 
Związek Czarnogóry uzyskał natomiast poparcie 7,9\% glosujących. Podział mandatów ukształtował się w sposób następujący: DPS - 36, SNP - 33, a LSCG - 6. Frekwencja wyborcza wynosiła $81,8 \%$ uprawnionych ${ }^{40}$. Misję utworzenia rządu ponownie otrzymał Filip Vujanović.

Po rozpadzie dotychczasowej koalicji rządzącej i niepowodzeniu w misji utworzenia kolejnego gabinetu Skupsztina dokonała samorozwiązania. Wybory przedterminowe zostały przeprowadzone w dniu 20 października 2002 roku. Zwyciężyła, utworzona przez prezydenta Milo Djukanovicia, koalicja „Demokratyczna Lista dla Europejskiej Czarnogóry”. Zyskała ona poparcie 44,8\% głosujących. Natomiast koalicja „Razem dla Zmian”, skupiona wokół SNP, uzyskała 35,9\% głosów. Liberalny Związek Czarnogóry utrzymał dotychczasowe poparcie (5,4\%). Do parlamentu swoich deputowanych wprowadziła również Demokratyczna Koalicja „Albańczycy Razem” (2,3\% głosów). Podział mandatów ukształtował się następująco: DPS - 39, SNP - 30, LSCG - 4 oraz koalicja albańska - 2 mandaty. Dnia 11 grudnia parlament udzielił votum zaufania nowemu rządowi, na czele którego po raz czwarty stanął Milo Djukanovićc1.

Kolejne wybory do Zgromadzenia Republiki odbyły się we wrześniu 2006 r., już po zerwaniu związku z Serbią. Przyniosły one sukces centrolewicowej koalicji premiera Milo Djukanovicia, która uzyskała 41 mandatów. Koalicja utworzona została przez dwie partie lewicowe: Demokratyczną Partię Socjalistów oraz Socjaldemokratyczną Partię Czarnogóry. Dwa opozycyjne bloki proserbskie uzyskały razem 23 mandaty, a nowe ugrupowanie - „Ruch na Rzecz Zmian” - wprowadziło 11 deputowanych. Frekwencja wyborcza wyniosła ok. 70\%. Wybory zakończyły się zwycięstwem ugrupowań opowiadających się za niezależnością Czarnogóry ${ }^{42}$. W listopadzie 2006 r. nowy rząd, w oparciu o zwycięską koalicję, utworzył Željko Šturanović. Rząd funkcjonował do lutego 2008 r., gdy dotychczasowy premier podał się do dymisji. Dnia 29 lutego 2009 roku nowy gabinet - w oparciu o dotychczasową koalicję - utworzył po raz piaty Milo Djukanović.

Ostatnie dotychczas wybory do Skupsztiny odbyły się w dniu 29 marca 2009 roku. Przyniosły one sukces koalicji utworzonej wokół DPS, na której kandydatów padło ponad 51\% głosów. W skład koalicji weszły także: SDP, Chorwacka Inicjatywa Obywatelska (HGI) oraz Partia Bośniacka (BS). Podział mandatów w koalicji prezentował się w sposób następujący: DPS - 35, SDP - 9, HGI - 1 oraz BS - 3. Na blok proserbski, złożony z SNP oraz Nowej Serbskiej Demokracji (NSD), oddano kolejno ponad

40 Zob. A. Burakowski, Jugostawia (Serbia i Czarnogóra), w: „Europa Środkowo-Wschodnia” 11-12 (2001-2002), Warszawa 2004, s. 379 i nast.

${ }^{41}$ Zob. A. Burakowski, op.cit., s. 396 i nast.

42 Zob. K. Krysieniel, J. Wojnicki, op.cit., s. 120 i nast. 
16,5\% głosów (razem 16 mandatów) oraz 9,1\% głosów (8 mandatów). „Ruch na rzecz Zmian" (PZP) poparło niespełna 6\% (5 mandatów). Po raz pierwszy od 1990 r. ugrupowania nawiązujące do ideologii liberalnej (LSCG) oraz narodowej (NS) nie zdołały wprowadzić swoich reprezentantów do Zgromadzenia. Frekwencja w elekcji wyniosła $65,2 \%$ uprawnionych do głosowania ${ }^{43}$. Misję utworzenia gabinetu po raz kolejny otrzymał Milo Djukanović, który sformował rząd w oparciu o cztery ugrupowania: Demokratyczną Partię Socjalistów (DPS), Partię Socjaldemokratyczną (SDP), Partię Bośniacką (BS) oraz Chorwacką Inicjatywę Obywatelską (HGI).

Tabela 1. Rządy Republiki Czarnogóry od 1991 roku

\begin{tabular}{|l|l|l|}
\hline \multicolumn{1}{|c|}{ Premier } & \multicolumn{1}{|c|}{ Czas trwania rządu } & \multicolumn{1}{c|}{ Koalicja rządowa } \\
\hline $\begin{array}{l}\text { M. Djukanović } \\
\text { DPS (trzy gabinety) }\end{array}$ & $02.1991-02.1998$ & DPS - rządy jednopartyjne \\
\hline $\begin{array}{l}\text { F. Vujanović } \\
\text { DPS }\end{array}$ & $02.1998-12.2002$ & DPS, SDP, NS \\
\hline $\begin{array}{l}\text { M. Djukanović } \\
\text { DPS }\end{array}$ & $12.2002-11.2006$ & DPS, SDP, GP, DUA \\
\hline $\begin{array}{l}\text { Ž. Šturanović } \\
\text { DPS }\end{array}$ & $11.2006-02.2008$ & DPS, SDP \\
\hline $\begin{array}{l}\text { M. Djukanović } \\
\text { DPS }\end{array}$ & $02.2008-04.2009$ & DPS, SDP \\
\hline $\begin{array}{l}\text { M. Djukanović } \\
\text { DPS }\end{array}$ & od 04.2009 & DPS, SDP, BS, HGI \\
\hline
\end{tabular}

Źródło: Opracowanie własne; DPS - Demokratyczna Partia Socjalistów Czarnogóry, SDP - Partia Socjaldemokratyczna, NS - Partia Narodowa, GP - Partia Obywatelska, DUA - Demokratyczna Unia Albańczyków, BS - Partia Bośniacka, HGI - Chorwacka Inicjatywa Obywatelska.

Reasumując, warto podkreślić, iż Czarnogóra stanowi przykład państwa postkomunistycznego, w którym od 1945 r. nie nastąpiła alternacja władzy. Władzę nadal sprawuje ugrupowanie postkomunistyczne, powstałe w $1990 \mathrm{r}$. w wyniku przekształceń wewnętrznych w ramach ówczesnego Związku Komunistów Czarnogóry. Główna oś konfliktu pomiędzy ugrupowaniami politycznymi odnosiła się do kwestii relacji z Serbią i tworzenia razem $\mathrm{z}$ nią państwa federacyjnego.

${ }^{43}$ Zob. www.parties-and-elections.de/montenegro.html, 15.04.2011. 


\section{The issue of government of the Republic of Montenegro in its executive system}

The Constitution of Montenegro describes the state as a "civic, democratic, ecological state of social justice, based on the reign of Law." Montenegro is an independent and sovereign republic that proclaimed its new constitution on 22th October 2007.

The President of Montenegro (Montenegrin: Predsjednik Crne Gore) is the head of state, elected for a period of five years through direct elections. The President represents the republic abroad, promulgates law by ordinance, calls elections for the Parliament, proposes candidates for Prime Minister, president and justices of the Constitutional Court to the Parliament. The President also proposes the calling of a referendum to Parliament, grants amnesty for criminal offences prescribed by the national law, confers decoration and awards and performs other constitutional duties and is a member of the Supreme Defence Council. The official residence of the President is in Cetinje. The Government of Montenegro (Montenegrin: Vlada Crne Gore) is the executive branch of government authority of Montenegro. The government is headed by the Prime Minister, and consists both of the deputy prime ministers as well as ministers. The Parliament of Montenegro (Montenegrin: Skupština Crne Gore) is a unicameral legislative body. It passes laws, ratifies treaties, appoints the Prime Minister, ministers, and justices of all courts, adopts the budget and performs other duties as established by the Constitution. Parliament can pass a vote of no-confidence on the Government by a simple majority. One representative is elected per 6,000 voters. The present parliament contains 81 seats, with a 47 -seat majority currently held by the Coalition for a_European Montenegro as a result of the 2009 parliamentary election.

\section{Le Gouvernement de la République du Monténégro dans le système des organes de l'État}

La Constitution du Monténégro définit ce dernier comme un État civique, démocratique, écologique, de la justice sociale et du règne de la loi. Le Monténégro est une république indépendante et souveraine qui a proclamé sa nouvelle constitution le 22 octobre 2007.

Le Président du Monténégro (monténégrin: Predsjednik Crne Gore) est le chef de l'État élu pour cinq ans au suffrage direct. Le Président représente la 
République à l'étranger, promulgue les lois, convoque des élections législatives, propose au Parlement des candidats au poste de Premier ministre, de président et de juges de la Cour constitutionnelle. Il peut également proposer un référendum. Le Président accorde l'amnistie des infractions pénales prévues par la législation nationale, confère des médailles et des prix et effectue d'autres tâches constitutionnelles. Il est membre du Conseil suprême de la défense. Cetinje est la résidence officielle du Président. Le gouvernement du Monténégro (monténégrin: Vlada Crne Gore) est l'organe exécutif, dirigé par le Premier ministre. Il se compose des vice-premiers ministres et des ministres. Le Parlement du Monténégro (monténégrin: Skupstina Crne Gore) est un organe législatif unicaméral. Il vote les lois, ratifie les traités, nomme le Premier ministre, les ministres et les juges de tous les tribunaux, adopte le budget et effectue d'autres fonctions établies par la Constitution. Le Parlement peut voter (à la majorité simple) une motion de censure contre le gouvernement. Un représentant est élu par 6000 électeurs. À la suite des élections législatives de 2009, le Parlement monténégrin compte 81 députés, y compris 47 députés de la coalition «Pour un Monténégro européen». 